
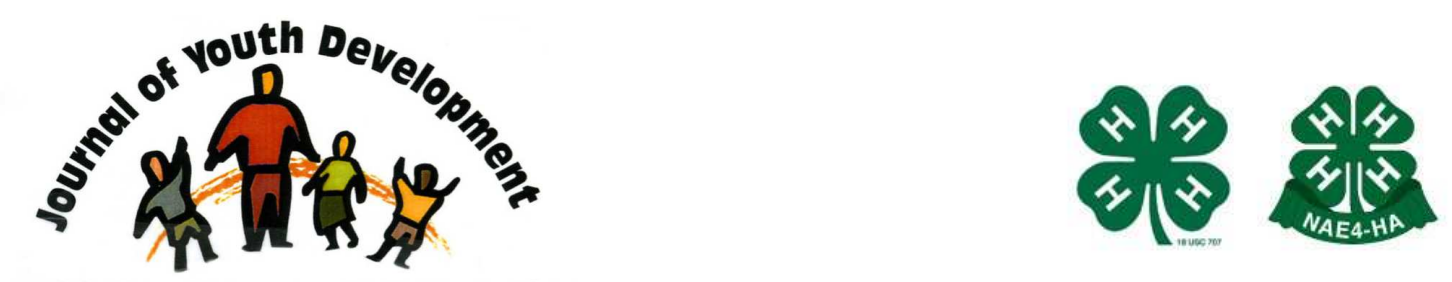

Bridging Research \& Practice

\title{
Engaging Youth in the Curriculum Development Process with Technology: The Nebraska State 4-H Youth Curriculum Committee
}

\author{
Michelle J. Garwood \\ Nebraska 4-H Curriculum Special Projects Coordinator \\ University of Nebraska-Lincoln Extension \\ Lincoln, NE \\ mgarwood2@unl.edu \\ Patricia J. Fairchild \\ Nebraska 4-H Curriculum Design \& Youth Entrepreneur Specialist \\ University of Nebraska-Lincoln Extension \\ Lincoln, NE \\ pfairchild2@unl.edu
}




\title{
JOURNAL OF YOUTH DEVELOPMENT \\ bridging research and practice

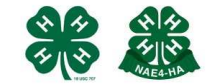

Volume 5, Number 1, Spring 2010

Article 100501PA001

\section{Engaging Youth in the Curriculum Development Process with Technology: The Nebraska State 4-H Youth Curriculum Committee}

\author{
Michelle J. Garwood and Patricia Fairchild \\ University of Nebraska-Lincoln
}

\begin{abstract}
Technology is changing the way youth learn and lead. This paper illustrates a successful case study of a program that actively engaged youth in the decision-making process through the use of an online community and virtual conferencing. Synergy was generated when the youth were mentored (virtually and in-person) by members of a parallel adult committee. Utilizing technology resources proved to be the key to building a vibrant, innovative and inclusive program that could overcome the barriers of time and travel constraints.
\end{abstract}

\section{Introduction}

In 1990 a marketing study was conducted to determine why youth typically leave the 4-H program. Results suggested that one major reason was that young people were "tired of being in an organization run by adults who thought they knew what was best for kids" (Hoover \& Weisenbach, 1999). Since that time, many efforts have been made at the national, state, and local levels to invite youth to the decision-making table. The 4-H program has been on the cutting edge of the youth governance movement that has been sweeping the nation during the past two decades.

Curriculum development is a strong component of the Nebraska 4-H program with more than twenty nationally-recognized manuals on the market. In recent years, the curriculum program has undergone substantive changes, including the review and revision of all existing curricula and the development of a curriculum committee to oversee all curriculum-related activities. During this period of transition and change, the need for youth voice was recognized as being essential for creating exciting, dynamic, cutting-edge educational material that meets the needs of today's youth. This is consistent with scholars' contentions that adults often come up short in fully understanding the interests of youth (Males, 1996). 
Research suggests that young people and adults bring different strengths to the decisionmaking table. When youth and adults work cooperatively, productivity and creativity are heightened. (Zeldin, Kusgen, McDaniel, Topitzes, \& Calvert, 2000). The mutual benefits of youth-adult partnerships are noted by several researchers. Youth typically see an increase in skills and form a sense of belonging while adults gain a greater understanding of youth needs. Stereotypes begin to break down and the organization and community begin to serve youth at a higher level (Bruce, Nicola, \& Menke, 2006; Gambone, Yu, Lewis-Charp, Sipe, \& Lacoe, 2004; MacNeil, 2000; Zeldin, Camino, \& Calvert, 2003).

As a result, Nebraska has established the State 4-H Youth Curriculum Committee. This group of thirteen youth ranged in age from 14-21, and is the first of its kind in the country. Instead of adding two or three seats for youth on the adult curriculum committee, Nebraska has created an independent, yet inter-connected, youth advisory board that seeks to complement the existing professional group. The committee is also unique in that it conducts much of its business virtually and relationships between members are developed through an online community.

\section{Committee Structure}

The 13 youth in the committee represent every 4-H curriculum content area (e.g., Animal Science, Communication and Expressive Arts, etc.) and Extension district in the state. Thus, the structure of the youth committee mirrors that of the professional group with geographic and content areas being represented.

Members from the professional committee mentor the youth in a variety of ways. In its initial year, the professionals partnered with youth members who shared common content areas of interest to work together on curriculum development projects. The youth were invited to contribute fresh ideas, review current material, and assist with piloting efforts. The youth were also mentored at the first-annual retreat by professionals who lead leadership lessons and guided the youth as they developed a program of work for the year. Through these experiences, the youth not only connected with caring adults who shared similar interests, but they became exposed to the Extension career field and the University. Much of this mentoring took place with the assistance of technology.

\section{Establishing Community Across the Miles With Technology}

A major challenge for youth programs today is keeping youth engaged, connected, and involved (Quinn, 1999). There are a number of activities (structured and unstructured) for young people to choose from today and they are known to "vote with their feet." The challenge is especially daunting with a group of youth who are scattered across several hundred, mostly rural miles.

Luckily, technology is now available that can help shatter the geographical barrier. Many workplaces have already successfully shifted to a more virtual organizational structure, which can serve as a model for youth development organizations (Wheeler, 2000). Today, millions of youth from all over the world participate in virtual communities such as My Space or Facebook. The popularity of online communities served as inspiration for creating a virtual community for the Youth Curriculum Committee.

The University of Nebraska-Lincoln has established an online community for classes and organizations. Blackboard is a secure system that is academically based and has a variety of 
features that enable virtual learning and collaboration. The Youth Curriculum Committee was established as an "Organization," a type of Blackboard Community with the following features: Announcements, Leader Profiles, Member Profiles, Handbook, Technology Support, Meeting Information, Assignments, Resources, External Links, Photo Scrapbook, Discussion Boards, Small Group Portals, Calendar, Document Sharing, Chat, E-mail, and Pod casting.

The Blackboard curriculum community is managed by a State 4-H Office staff member. Administrative rights can be given to specific individuals and involves the ability to post information, monitor discussion boards, track participation, establish small group portals, etc. Those designated as "participants" can participate in discussions, chat, share documents, email, and view information, but can not post documents, announcements, etc.

Blackboard served as a place for youth and their professional mentors to get to know each other despite being hundreds of miles apart. They enjoyed the freedom to be expressive and established identity through their profiles and discussion posts. As the community developed, youth were encouraged to take ownership of the community by designing the site banner, submitting photographs, and leading discussions and small group work.

Blackboard also made it possible to accomplish work in-between meetings. Decisions were made via e-mail, discussion board, or chat. Small groups were established and members were encouraged to send working documents back and forth. Curriculum was reviewed and critiques were posted to the discussion board. Online meetings were recorded and made available to those who were absent.

\section{Meeting Virtually}

Conducting online meetings is another way to eliminate the barriers of distance and hectic schedules (Young \& Sazama, 1999). Today's technology is making the experience more realistic than ever. The University and 4-H program utilizes Breeze conference technology to conduct professional meetings. Therefore, it was a natural choice to utilize Breeze to connect the youth committee members.

The first Curriculum Committee meeting was held on April 9, 2007. Care was taken to identify a meeting date that generated the least conflict between school and activity schedules. It was the first time that all of the youth members had been exposed to Breeze. To participate, members were required to log in to the Breeze meeting website. Once they had entered the meeting, they were asked to submit a phone number so the conference operator could connect them to the audio portion of the meeting.

In order to help the youth members become comfortable with the virtual meeting format, business was kept to a minimum (50 minutes) and mainly focused on introductions, a Q and A session about the technology and a brief introduction to the work that would be pursued throughout the year. The meeting was fast-paced, high energy, and encouraged youth look forward to the year ahead. Plans began to take shape for an in-person retreat within the next couple of months where the youth would come together and do major planning and teambuilding. Small assignments were given to keep the youth connected and interested between the initial meeting and the retreat.

As the members became more comfortable with the virtual meeting environment, they were asked to take ownership of more aspects of the meeting. For example, youth were asked to 
contribute reports and presentations on their work, ask for input from other members, participate in chat, conduct polls, connect with web cams, and contribute to the agenda.

\section{Youth Teaching Youth with Technology}

Not only did the youth committee utilize technology to conduct meetings and exchange ideas, they utilized it to teach and inspire their peers across the state. In addition to developing curricula, committee members challenged themselves with the task of promoting 4- $\mathrm{H}$ projects through technology-related activities.

The Nebraska State Fair Cyber Fair, established in 2001, is a website and yearly event involving cutting-edge technology exhibits that help families explore and interact with 4-H curriculum. This year the youth curriculum committee played an integral role in adapting the state event to several smaller satellite events across the state. The youth taught their peers about the online learning opportunities available through this program and made plans to expand the site in the future. Future plans include the development of educational pod casts and online tutorials that will help youth learn about topics from entrepreneurship to clothing design.

\section{Conclusion}

The saying goes, "if you build it, they will come." Across the nation, youth are demanding to have a voice in the organizations and institutions that affect their daily lives. Nebraska 4-H curriculum has "built" the playing field for youth to participate in the decision-making process and thirteen youth have stepped up to the plate. The time has come to let the synergy of youth-adult partnerships shape the future of the program. Technology will be the key to building a vibrant, innovative and inclusive program that can overcome the barriers of time and travel constraints.

At this time, the Youth Committee is only designed to work with in the 4-H program at our University, although the model for the committee could be used in any youth organization needing to increase youth participation in decision-making processes. It is especially helpful for groups spread out over a wide geographic area or who have extremely busy members who struggle to connect in person on a regular basis.

\section{References}

Gambone, M., Yu, H., Lewis-Charp, H., Sipe, C., \& Lancoe, J. (2004). A Comparative Analysis of Community Youth Development Strategies. Circle Working Paper, University of Maryland.

Hoover, A.B., \& Weisenbach, A. (1999). Youth leading now! Securing a place at the table. New Designs for Youth Development, 15(3), 29-35.

Males, M. (1996). The scapegoat generation: America's war on adolescents. Monroe, MN: Common Courage Press.

Quinn, J. (1999). Where need meets opportunity: Youth development programs for early teens. When School is Out, $9(2), 96-116$. 
Wheeler, W. (2000). Emerging organizational theory and the youth development organization. Applied Development Science, 4(1), 47-54.

Young, K.S., \& Sazama, J. (1999). Fourteen points: Successfully involving youth in decisionmaking. (Available from Youth on Board, 58 Day Street, Third Floor, P.O. Box 440322, Somerville, MA 02144).

Zeldin, S., Camino, L., \& Calvert, M. (2003). Toward an understanding of youth in community governance: Policy priorities and research directions. Social Policy Report, vol. XVII, No. III Ann Arbor, MI: Society for Research In Child Development. http://www.srcd.org/sspr.html

Zeldin, S., Kusgen McDaniel, A., Topitzes, D., \& Calvert, M. (2000). Youth in decision making: A study of the impacts of youth and adults on organizations. University of Wisconsin-Madison, Department of Human Development and Family Studies.

(C) Copyright of Journal of Youth Development $~$ Bridging Research and Practice. Content may not be copied or emailed to multiple sites or posted to a listserv without copyright holder's express written permission. However, users may print, download or email articles for individual use. 